\title{
INTEGRATED LOGISTICS SUPPORT OF LOCAL GOVERNMENT UNITS - CONCEPT AND REASONS
}

DATA PRZESŁANIA: 19.05.2018, DATA AKCEPTACJI: 06.05.2018, JEL CODE: R49

\author{
Izabela Dembińska \\ Wydział Zarządzania i Ekonomiki Usług, Uniwersytet Szczeciński \\ e-mail: izabela.dembinska@wzieu.pl
}

\section{Łukasz Marzantowicz}

Kolegium Nauk o Przedsiębiorstwie, Szkoła Główna Handlowa w Warszawie e-mail: lukasz.marzantowicz@sgh.waw.pl of logistics considerations, occupies an even more important place. On the one hand, the question is whether logistics in LGU should be considered as an element of effective management and, on the other hand, logistic activities should be considered in terms of support. The differences in consistency and scope of logistic activities (and logistical support) at different levels of LGU have been assumed to be the basic issue. The reflections were based on theoretical assumptions about the possibilities of using logistic processes and actions in the functioning of local government units. The article has a theoretical character. The logistic paradigm has attempted to define integrated logistical support for local government units. Using the method of secondary analysis of documents and the deduction technique, the possibility of proposing the concept of vertical integration of logistic support measures in local government units was proposed. To this end, the scope of logistic support for territorial self-government units has been characterized, taking into account the voivodship, poviat and commune levels. Identification and discussion of the concept of integrated logistic support of the territorial self-government units has been identified and implemented thus realizing the purpose of the article aiming at identifying possibilities of integration of logistic support measures as a contribution to the economic and social development of Poland's regions.

territorial self-government unit, integrated logistic support 


\section{INTRODUCTION}

The organization of social life in the region is largely dictated by the implementation of statutory tasks of local self-government units (LGU).In the context of the logistics system of the region, logistics subsystems of the commune, poviat and voivodship, it is important to look at the logistics and logistics management in local government units in a systemic way, especially taking into account the holistic approach. It points out the element of integrity as the immanent attribute of the system approach to process management, including the processes implemented by LGU.

The three-structural functioning of the council (commune, district, province) in a diversified way and in many cases uncorrelated with each other becomes a contribution to the creation of integrated logistics processes concept in local government. Noticeable is the fact not recognizing the possibility of identifying common goals of units mounted on all three levels of local government.

Logistic support understood as a set of auxiliary logistics activities in the processes implemented by LGUs can be seen as a kind of local government units integrator. The proposal of vertical integration of tasks between individual levels of local government units and the integration of logistic support in the same vertical way becomes a contribution to the concept creation of which the basic premise is the impact on the effectiveness of the region's economic development.

The aim of this article is to identify opportunities and create the optimum system solutions for logistics' support implementation of the statutory tasks of local government, thereby initiating discussion on this subject. The proposed concept of integrated logistic support for local government units and defining the vertical integration areas of LGU logistics support leads the authors' thought path towards the holistic approach to logistics and functioning of local government units.

In view of starting theoretical considerations on the proposed concept, it is not possible to determine the division of responsibility over the implementation of the concept by individual JST authorities. There is no motive yet to refer to the law sanctioning of the above solutions, which also makes it impossible to determine the implementation way and only susceptible areas for the concepts application of integrated logistic support for LGUs. However, choosing the premises that justify the proposed approach causes that the article should be treated as the voice initiating polemic.

\section{CURRENT STATE OF KNOWLEDGE BASED ON LITERATURE REVIEW OF THE PROBLEM}

The subject of logistics and local government units can be considered as quite extensively researched. Only over the internet, over 5 years, you can find over 14,000 Polish and foreign language publications answering the logistics as a key word. There are over 11,000 publications about local government units in the same period. The period of 5 years, as relatively short, indicates just over 5,000 publications in the field of logistic support. The scope of the use of logistics in LGUs included in publications over a 5 -year period is only around 1,000 publications. The topic of logistical support in local government units, in the same period, is only 800 publications. None of these publications addresses problems in a systematic manner. Such a small number 
of publications addresses topics embedded in a given specificity, i.e. logistic support in rural areas, agrologistics, infrastructure and local tourism, etc. There are also publications regarding the use of logistics or logistic support in local logistics centers, transport and communication. These are just some of the selected thematic areas, but allow to note the focus of these publications around areas directly affecting the economic development of the region, however, not referring to system concepts, combining several areas in one aspect of the use of logistics in LGUs. This period of 5 years is undoubtedly not long enough, but as regards the exploration level of the logistics subject and the period in which the division of territorial self-government units is in force in Poland, scientific achievements should be considered as small and still leave a large cognitive space.

\section{LOGISTIC SUPPORT OF LOCAL GOVERNMENT UNITS}

Local government units (LGUs) operate as public institutions in a regional environment in a legally regulated way. From the point of view of the regional economy, the surrounding of LGUs is not only a set of public institutions, for which local government units are responsible, fulfilling statutory (and constitutional) tasks. There are also enterprises, non-public institutions and the local community also create the environment. Everyone (and especially the local community) are recipients of the effects of tasks completed by LGUs.

The structure between territorial units is defined in art. 163. and 164. Constitution of the Republic of Poland, pointing to the three-level division: commune, poviat and voivodship. However, the basic unit in accordance with art. 164 of the Constitution is a commune, and the activities of units from the third division are regulated respectively by the laws on commune, poviat and voivodeship self-government (Dz.U. 2016, poz. 446; Dz.U. 2015, poz. 1145; Dz.U. 2015, poz. 1392). These laws do not indicate a subordinate dependence of local government units. Therefore, it is possible to put forward the thesis that despite pointing to specific tasks of territorial self-government units at various levels, the existing logistical support (if it can be talked about logistic support rather than the use of logistics management elements) is carried out independently, i.e. without indication of the relations between local government units and without consistency of the effects of the tasks being performed, which may lead to inferior effectiveness and efficiency in the economic development of the region. Although the diversification of tasks is dictated by the various responsibilities of LGUs, the economic development (social, economic, innovative, technological, etc.) of the region could constitute a common (realistically related and dependent on each other) goal of all three units. The daring of the aforementioned thesis results from several aspects of understanding the logistic support. For behold, logistical support previously defined does not cause problems with his understanding for each (single) local unit. The fact should be considered that the logistic support of LGUs will be directed at the issue of managing flows (personal, financial, material, information) as well as spatial planning, access to resources (including institutional resources) and horizontal integration of processes at a given level. The next aspect is a reference to the concept of management (and control) of flows - in analogy to the internal and external supply chain and to the system approach, especially the holistic approach. The resource stream is different at individual levels of local government units (respectively different at the level of the commune, poviat and voivodship), although the effects 
of tasks related to e.g. spatial development should be expected in the form of common values in the region's economic approach. The last important aspect is the social economy. Here, logistic support can only apply to ensuring access to shared resources. Again diversified depending on the level of local government.

Logistic support (as a set of relatively auxiliary logistics activities) in LGUs literally concerns:

a) spatial management and accessibility (including exploitation) to resources;

b) access to institutions;

c) access to information (in the field of land resources, work, people, technologies) and the possibilities of their processing;

d) support for preventive processes of crisis situations and organization of leveling their effects;

e) financial flows (including accessibility to sources of financial stream);

f) urban logistics (city logistics) and logistics of public services (supply of basic utilities, and technical service as well as waste management);

g) logistic systems of local enterprises (in the field of access to infrastructure and land and human resources);

h) providing access to health care (accessibility to local health care centers);

i) public security, (army, police, fire brigade);

j) quality of life, (social housing, environmental protection, organization of the social life space);

k) accessibility to innovation (e.g. renewable energy), technology and education (knowledge and science).

In view of the indications that the tasks completed (by law) by LGUs are not subject to vertical integration, the set of proposed references to the functioning of logistic support in LGUs has an informal (and unstructured) nature, since the division of references depends on the three-fold scope of obligatory tasks. This approach is the implication of a holistic view on the integration's problem of tasks, effects and the common goal of LGUs. The systemic approach in this area determines the direction of logistic processes' effective management (in the concept of logistic support for LGUs and, as a consequence, the designation of its role). This, in turn, leads to the search for the answer to the question of how the integration of LGUs logistic support can proceed, and what determinants it is caused by?

\section{THE PLANE OF INTEGRATION OF LOGISTIC SUPPORT FOR LOCAL GOVERNMENT UNITS}

Systemic approach understood as the leading paradigm of logistics (Pfohl, 2001, p. 40; Senge, 2000; Penc, 1996) in the concept of using logistic support LGUs acquire the role of an integrator of tasks completed by local government units and individual logistics subsystems of the commune, poviat and voivodship. The system is a whole that fulfills the postulate of integrity (Okulewicz, 2004, pp. 479-488). Integrity means creating a common value in the form of goals and effects, and not just cooperation in a given level of agreement (Oliver, Webber, 1982). The systemic approach shapes the holistic image of the JST logistic support integration structure. In fact, the determinant of integrated logistic support for local government units is the possibility of vertical integration 
of tasks implemented by individual levels of LGUs. The joint implementation of statutory tasks leads to an increase in the pace of achieving the desired effects. Therefore, the structural concept of integrated logistic support for local government units is shown in figure 1.

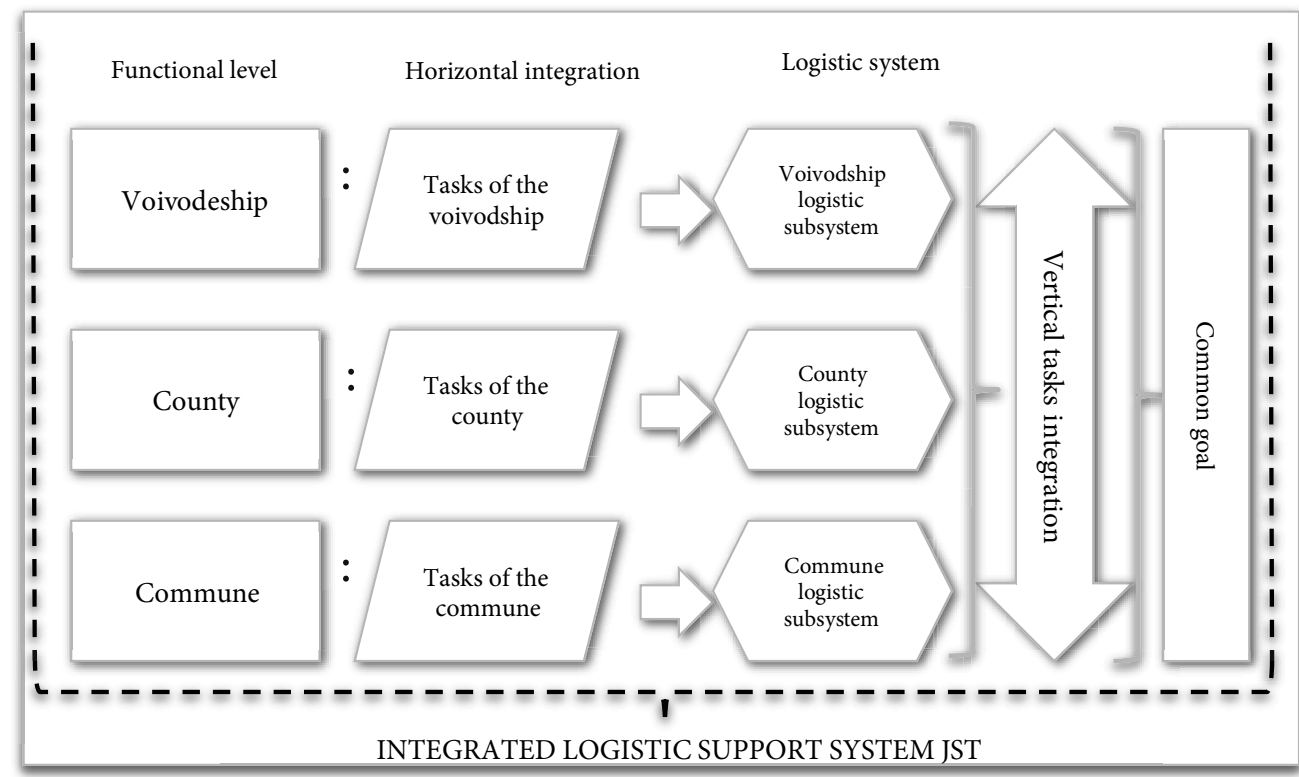

Figure 1. The concept of integrated JST logistic support

Source: own study.

The concept indicated in Figure 1 is a contribution to the discussion on the location of logistic support for local government units and its role in the region's logistics system (understood as the cooperation of the areas of the commune, poviat and voivodship on the logistics management and local government effects). For obvious reasons, the concept described cannot be considered the only binding one yet. However, factors determining this way of thinking can be included in the attempt to delineate the definition of integrated logistic support for LGUs. Integrated logistic support of local government units is an organized (consistently) system of relative (interdependent and logical sequence of activities) logistic activities, efficiently leading to an increase in the level of effectiveness of tasks of local government units based on vertically integrated cooperation creating consolidated effects. The chosen definition of integrated logistic support of LGU is, of course, the beginning of a possible discussion in the problem. However, the chosen concept also requires defining integration areas based on the role and location of integrated logistic support in the region's logistics system, as shown in table 1.

The presented approach to the concept of integrated logistics support of local government units cognitive open space in this area. It is not yet possible to talk about a specific blending of concepts (semantics), but a systematic view on the problem is made that allows the current 
observation of the use of logistics in the public life organization and the environment of society functioning. In view of the role of logistic support for LGUs and the need to increase the integrity level in the tasks of individual local government units, the proposed concept is justified.

Table 1. Characteristics of the vertical integration of JST logistical support

\begin{tabular}{|c|c|c|c|}
\hline $\begin{array}{c}\text { The JST level } \\
\text { Area of integration }\end{array}$ & Commune & County & Voivodeship \\
\hline $\begin{array}{l}\text { 1. Access to the region's } \\
\text { resources. (Spatial } \\
\text { development, access } \\
\text { to institutions } \\
\text { and infrastructure) }\end{array}$ & $\begin{array}{l}\text { Rational management } \\
\text { of land resources } \\
\text { and logistics infrastructure, } \\
\text { spatial development }\end{array}$ & $\begin{array}{l}\text { Technical } \\
\text { and technological } \\
\text { support in land } \\
\text { and infrastructure } \\
\text { management }\end{array}$ & $\begin{array}{l}\text { Regional support } \\
\text { programs for management } \\
\text { and availability of resources, } \\
\text { spatial planning }\end{array}$ \\
\hline $\begin{array}{l}\text { 2. City logistics and public } \\
\text { services logistics (including } \\
\text { municipal services, utilities, } \\
\text { transport, communication } \\
\text { and waste management) }\end{array}$ & $\begin{array}{l}\text { Waste management, } \\
\text { promoting } \\
\text { pro-ecological attitudes } \\
\text { in the field of public } \\
\text { transport and the use } \\
\text { of logistics and transport } \\
\text { infrastructure resources. } \\
\text { Support for regional } \\
\text { development and support } \\
\text { for projects affecting } \\
\text { economic development }\end{array}$ & $\begin{array}{l}\text { Communicating } \\
\text { communal regions, } \\
\text { spatial development } \\
\text { support, implementation } \\
\text { of basic assumptions } \\
\text { of development region's } \\
\text { plans }\end{array}$ & $\begin{array}{l}\text { Public and freight transport } \\
\text { system of the region. } \\
\text { Communication development } \\
\text { plans. Systems for waste } \\
\text { utilization, utilization } \\
\text { and utilization. Ensuring } \\
\text { access to basic transmission } \\
\text { media }\end{array}$ \\
\hline $\begin{array}{l}\text { 3. Quality of life. } \\
\text { (Access to the health care } \\
\text { system, support for crisis } \\
\text { situations, securing basic } \\
\text { human needs, public safety) }\end{array}$ & $\begin{array}{l}\text { Implementing } \\
\text { the postulates of enabling } \\
\text { access to healthcare. } \\
\text { Fulfilling the preventive } \\
\text { role in crisis management. } \\
\text { Supporting subordinate } \\
\text { units in public security } \\
\text { management. Support } \\
\text { for human existence }\end{array}$ & $\begin{array}{l}\text { Implementation of spatial } \\
\text { development plans } \\
\text { enabling access to health } \\
\text { care. Spatial economy in } \\
\text { the field of preventing } \\
\text { and eliminating } \\
\text { the effects of disasters. } \\
\text { Support for human } \\
\text { existence }\end{array}$ & $\begin{array}{l}\text { Regional plans for protection } \\
\text { against disasters and crises. } \\
\text { Access to public health } \\
\text { centers. Functional security } \\
\text { and prose reactions in } \\
\text { the field of public safety }\end{array}$ \\
\hline $\begin{array}{l}\text { 4. Access to innovation. } \\
\text { (Access to information, } \\
\text { technology, knowledge, } \\
\text { science, resources, finances, } \\
\text { etc.) }\end{array}$ & $\begin{array}{l}\text { Supporting pro-ecological } \\
\text { attitudes of enterprises, } \\
\text { green public procurement, } \\
\text { development plans based } \\
\text { on locations of renewable } \\
\text { energy sources, availability } \\
\text { of financing, low-emission } \\
\text { economy. Support } \\
\text { for innovative enterprises, } \\
\text { access to knowledge, } \\
\text { support for know-how }\end{array}$ & $\begin{array}{l}\text { Organizing } \\
\text { spatial allocation } \\
\text { of RES, implementation } \\
\text { of proecological economy } \\
\text { postulates, support for } \\
\text { eco-enterprises, } \\
\text { information support, } \\
\text { access to infrastructure, } \\
\text { technical (infrastructure) } \\
\text { security, infrastructure } \\
\text { availability } \\
\text { for the implementation } \\
\text { of innovative projects }\end{array}$ & $\begin{array}{l}\text { Organization } \\
\text { and planning of public space } \\
\text { for the implementation } \\
\text { of innovative projects, } \\
\text { Regional development } \\
\text { of pro-ecological } \\
\text { attitudes, Management } \\
\text { of the space of knowledge } \\
\text { and science, management } \\
\text { of knowledge resources } \\
\text { and technologies. Support } \\
\text { for RES technologies, } \\
\text { availability of financing } \\
\text { industry, production, } \\
\text { transport, communication } \\
\text { and businesses oriented to } \\
\text { smart development }\end{array}$ \\
\hline
\end{tabular}

Source: own study. 


\section{PREMISES OF STRIVING FOR A SYSTEM OF INTEGRATED LOGISTIC SUPPORT FOR SELF-GOVERNMENT COMMUNITIES}

In essence, the economic efficiency of the region is the effects level of the tasks implementation of self-government communities (whose recipients are enterprises, institutions and the local community). Assuming the three-part implementation of the above-mentioned tasks, attention is paid to diversifying responsibilities and extending the duration of ventures. Extending the duration of the project always has a negative impact on the assessment of the level of efficiency in its implementation, and thus reduces the degree of efficiency. Assuming that such a problem is addressed by the concept of integrated logistic support of LGUs (based on a previous attempt to define it and define areas of integration), the following premises can be selected:

1. Social premises:

- Social disintegration, barriers to the creation of regional communities, difficulties in access to basic health care, slow development of societies, demography, migrations, lack of jobs, barriers to access to knowledge (and education), restrictions on public safety, unstable living standards, functional social support.

2. Economic premises:

- Tax allocation, barriers to the financing of regional enterprises, lack of tax breaks, disintegration of economic development, prolonged project implementation time, distribution of operating costs in the region, increased operating costs of enterprises, investment barriers, high land prices, high prices of access to information, high costs diversifying responsibility for crisis management.

3. Technological premises:

- Barriers in organizing modern production technologies, lack of support in financing innovative solutions, high costs of technology implementation, barriers to access to technological novelties, barriers in organization of technological waste, barriers to access to investment areas, barriers to obtaining necessary permits, debts the period of obtaining patent certificates, barriers in the creation of assistance and preventive systems in crisis management.

4. Quality premises:

- Speed of investment support, barriers to access to state-of-the-art system solutions in information technologies, restrictions on access to information (internet), lack of support in spreading pro-quality attitudes of local enterprises, limitations in the quality of logistics, transport, transmission and IT infrastructure.

5. Ecological premises:

- Lack of support for pro-ecological attitudes, limitations in access to logistic infrastructure supporting ecological investments, restrictions on access to areas for ecological activities, barriers to promoting renewable energy sources, ineffective low-carbon economy, extended investment time through a complicated formal process, high costs of running eco-business, lack of implementation support, barriers in financing pro-ecological projects. 
6. Development premises:

- Limitations in access to expert knowledge, lack of effective regional enterprise support systems, lack of implementation assistance in the field of introducing new technologies, high volatility of the law, infrastructural restrictions, restrictions on access to regional resources, lack of human resources, formal restrictions in the investment process, lack of JST participation in the cost-intensive investment process, restrictions on access to e-commerce.

The main reasons for creating integrated logistic support of LGUs are determined by the tripartite of self-government communities' tasks. In principle, the grouping of integrated support concept of local government units as one of the possible solutions is based on the same division. From the logistics point of view, in each area of LGUs activity there is a possibility to use the concept of logistic support system. Vertical integration of LGUs tasks is a contribution to the search for optimal and rational system solutions.

\section{CONCLUSION}

The concept of integrated logistic support for local government units is just one of the proposals in the positioning of logistics in the local social space. Local self-government communities are responsible for the economic development of the regions. The duality of approach to logistics as the mainstream of management and support system still leaves room for discussion on which aspects will apply to the tiers of local government units. In fact, processes based on LGUs management can not be deprived of logistic aspects. As a consequence, processes in the local government units' activities require a logistic support at least.

Integration of LGU tasks and logistic support of LGUs is basically a response to the postulates of the region's economic efficiency. In defined aspects of the pace of development and related constraints, the cognitive space for determining the role of logistics in regional social life is broad. And the concept of integrated logistic support for LGUs should be considered as one of the starting points in the recognition of the scientific (research) plane of the taken subject.

The formal scope of tasks of individual local government units and the lack of a formal definition of the subordinated dependence of LGUs means that the main barrier to the concept implementation of LGUs integrated logistic support is the independence functioning of self-government communities. Although there is no multiplication of similar tasks, their connection and integration into one process (vertically integrated) without creating a formal structure (legally sanctioned) is a challenge to the efficiency of management process in LGUs. There is a need to use a systematic approach to the management of the region's logistics system in a holistic way. The lack of inter-institutional relations in LGUs at the level of generating common, efficiently pursued goals is in fact a barrier to effective economic development of the region.

The literature review has shown that in the area of logistics use in LGUs, there are Polish and foreign publications, with a highly focused nature only on selected aspects of the subject (agrologistics, logistics in crisis situations, health care, spatial planning, etc.). The lack of discussion on defining the role of logistics in LGU in a holistic approach is clearly visible. This presupposes (a relatively small number of publications in the discussed problem) that apart from 
the lack of mainstreaming in similar considerations, the cognitive sphere and the exploration of the logistics subject in LGUs are still open.

\section{REFERENCES}

Okulewicz, J. (2004). Kryteria analizy systemów transportowych. Warszawa: Międzynarodowa Konferencja Naukowa Transport XXI wieku.

Oliver, R.K., Webber, M.D. (1982). Supply-chain management: logistics catches up with strategy. Outlook, Booz Allen \& Hamilton Inc. In: M. Christopher (red.), Logistics. The strategic issues (pp. 479-488). Chapman \& Hall.

Penc, J. (1996). Strategie zarządzania. Perspektywiczne myślenie. Systemowe działanie. Warszawa: Placet.

Pfohl, H.Ch. (2001). Systemy logistyczne, Podstawy organizacji i zarządzania. Poznań: Biblioteka Logistyka.

Senge, P. (2000). Piata dyscyplina. Warszawa: ABC.

Ustawa o samorządzie powiatowym. Dz.U. 2015, poz. 1145.

Ustawa o samorządzie województwa. Dz.U. 2015, poz. 1392.

Ustawa o samorządzie gminnym. Dz.U. 2016, poz. 446.

\section{Zintegrowane wsparcie logistyczne jednostek samorządu terytorialnego - koncepcja i jej przesłanki}

\begin{tabular}{l|l} 
STRESZCZENIE & $\begin{array}{l}\text { Wsparcie logistyczne jednostek samorządu terytorialnego w Polsce stanowi temat, który w zakresie } \\
\text { rozważań o logistyce zajmuje coraz ważniejsze miejsce. Z jednej strony poszukuje się odpowiedzi } \\
\text { na pytanie, czy logistyka w JST rozpatrywana powinna być jako element skutecznego zarządzania, } \\
\text { a z drugiej strony czy działania logistyczne należy jednak rozpatrywać w kategoriach wsparcia. Za } \\
\text { podstawowy problem przyjęto różnice w spójności i zakresie działań logistycznych (i wsparcia logi- } \\
\text { stycznego) na różnych szczeblach JST. Rozważania oparto na teoretycznych przesłankach możliwo- } \\
\text { ści wykorzystania procesów i działań logistycznych w funkcjonowaniu JST. Artykuł ma charakter } \\
\text { teoriopoznawczy. Na kanwie paradygmatu logistyki dokonano próby zdefiniowania zintegrowane- } \\
\text { go wsparcia logistycznego JST. Wykorzystując metodę analizy wtórnej dokumentów źródłowych } \\
\text { oraz technikę dedukcji, przyjęto możliwość zaproponowania koncepcji pionowej integracji działań } \\
\text { wsparcia logistycznego w JST. W tym celu scharakteryzowano zakres wsparcia logistycznego dla } \\
\text { JST z uwzględnieniem szczebli: wojewódzkiego, powiatowego i gminnego. Zidentyfikowano i omó- } \\
\text { wiono przesłanki koncepcji zintegrowanego wsparcia logistycznego JST, realizując w ten sposób cel } \\
\text { artykułu dążący do identyfikacji możliwości integracji działań wsparcia logistycznego jako przy- } \\
\text { czynku do rozwoju gospodarczego i społecznego regionów Polski. }\end{array}$ \\
$\begin{array}{l}\text { SŁOWA KLUCZOWE } \\
\text { jednostka samorządu terytorialnego, zintegrowane wsparcie logistyczne }\end{array}$
\end{tabular} 